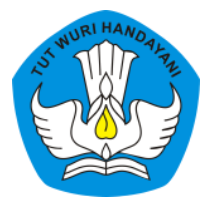

Page: 487-506

\title{
KETERAMPILAN BERPIKIR KRITIS DALAM PEMBELAJARAN BERBASIS MASALAH BERBANTUAN SITUS JEJARING SOSIAL EDMODO
}

\author{
Siti Rosiyanah \\ Sekolah Menengah Pertama Negeri 6 Jepara, Jawa Tengah, Indonesia \\ Contributor Email: sitirosiyanah749@gmail.com
}

Received: Feb 15, 2021

Accepted: Jun 10, 2021

Published: Jul 30, 2021

Article Url: https://ojsdikdas.kemdikbud.go.id/index.php/didaktika/article/view/367

\begin{abstract}
The rapid development of informatics and computer (ICT) techniques has an impact on education today. On the other hand, the changing paradigm of education that used to embrace teacher-centered learning into student-centered learning has brought significant changes to the learning methods developed today. This study aims to determine the effectiveness of problem-based learning models assisted by Edmodo social networking site on critical thinking skill and student learning outcomes. This research was conducted in class VIII of SMP Negeri 6 Jepara in the odd semester of 2019/2020 Academic Year on the material of pressure and its application in daily life. The research design used was the pre-test and post-test control group design. Data retrieval is done by observation, documentation and tests. The results showed that the value of $t_{\text {count }}$ critical thinking skills and student learning outcomes $>t_{\text {table }}$ value (1.99). The value of $t_{\text {count }}$ critical thinking skills and learning outcomes respectively is 11.12 and 2.757. The result of this study concluded that the problem based learning model supported by Edmodo's social networking site is effective to improve critical thinking skills and students learning outcomes.
\end{abstract}

Keywords: Problem Based Learning; Edmodo; Critical thinking. 


\begin{abstract}
Abstrak
Perkembangan teknik informatika dan komputer (TIK) yang semakin pesat membawa dampak terhadap dunia pendidikan saat ini. Perubahan paradigma pendidikan yang dulunya menganut teacher-centered learning menjadi student-centered learning, membawa perubahan yang sangat signifikan terhadap metode-metode pembelajaran yang dikembangkan saat ini. Penelitian ini bertujuan untuk mengetahui keefektifan model pembelajaran berbasis masalah berbantuan situs jejaring sosial Edmodo terhadap keterampilan berpikir kritis dan hasil belajar peserta didik. Penelitian ini dilakukan di kelas VIII SMP Negeri 6 Jepara pada semester gasal Tahun Pelajaran 2019/2020 pada materi tekanan dan penerapannya dalam kehidupan sehari-hari. Desain penelitian yang digunakan adalah pre-test and post-test control group design. Pengambilan data dilakukan dengan metode observasi, dokumentasi, dan tes. Hasil penelitian menunjukkan bahwa nilai thitung keterampilan berpikir kritis dan hasil belajar peserta didik $>$ nilai $t_{\text {tabel }}(1,99)$. Nilai $t_{\text {hitung }}$ keterampilan berpikir kritis dan hasil belajar secara berturut-turut adalah 11,12 dan 2,757. Hasil penelitian menyimpulkan bahwa model pembelajaran berbasis proyek berbantuan situs jejaring sosial Edmodo efektif untuk meningkatkan keterampilan berpikir kritis dan hasil belajar peserta didik. Hasil penelitian menyimpulkan bahwa model pembelajaran berbasis masalah berbantuan situs jejaring sosial Edmodo efektif untuk meningkatkan keterampilan berpikir dan hasil belajar peserta didik.
\end{abstract}

Kata Kunci: Pembelajaran Berbasis Masalah; Edmodo; Berpikir Kritis.

\title{
A. Pendahuluan
}

Perkembangan teknologi informatika dan komputer (TIK) yang semakin pesat membawa dampak terhadap dunia pendidikan saat ini. Di sisi lain, berubahnya paradigma pendidikan yang dulunya menganut teacher-centered learning menjadi student-centered learning, membawa perubahan yang sangat signifikan terhadap metode-metode pembelajaran yang dikembangkan saat ini (Basori, 2013). Guru sudah mulai mengarahkan peserta didik untuk meningkatkan pengetahuan dengan memanfaatkan fasilitas yang menunjang. Fasilitas yang dimaksud adalah kemudahan penggunaan internet di sekolah serta pemanfaatan jejaring sosial untuk pendidikan.

Perkembangan terbaru dari jejaring sosial seperti Facebook dan Twitter membawa peluang baru tidak hanya untuk bersosialisasi, tetapi juga untuk berbagi pengetahuan dan pembelajaran (Eid \& Al-Jabri, 2016). 
Namun Junco (2013) mengemukakan dalam penelitiannya bahwa banyak peserta didik yang menghabiskan waktunya untuk membuka Facebook untuk hiburan semata.

Salah satu situs jejaring sosial pada saat ini sangat berkembang pesat, salah satu di antaranya adalah Edmodo. Edmodo merupakan situs jejaring sosial berbasis lingkungan sekolah (school based environment). Edmodo diciptakan menggunakan konsep social networking, yang mengacu pada jejaring sosial Facebook sehingga sistem ini memiliki fitur yang mirip dengan Facebook (Basori, 2013). Selain untuk media jejaring sosial, Edmodo juga mendukung blended learning yaitu pembelajaran yang menggabungkan antara sistem pembelajaran tatap muka dan pembelajaran daring yang bisa diberikan oleh siapa saja, di mana saja, dan kapan saja (Sudarman, 2018). Situs jejaring sosial ini baik digunakan sebagai alat tambahan bagi pembelajaran di kelas karena memungkinkan peserta didik untuk meningkatkan belajar mereka melalui partisipasi aktif dalam diskusi online (Enriquez, 2014).

Pemanfaatan jejaring sosial bisa dikolaborasikan dengan model pembelajaran yang sudah ada, seperti model pembelajaran berbasis masalah sebagai suatu strategi atau pendekatan yang dirancang untuk membantu proses belajar sesuai dengan langkah-langkah yang terdapat pada pola pemecahan masalah yakni mulai dari analisis, rencana, pemecahan, dan penilaian yang melekat pada setiap tahap (Tany \& Utami, 2013). Model pembelajaran ini melibatkan peserta didik secara aktif dalam proses pembelajaran, mengaitkan materi dengan masalah-masalah nyata yang memungkinkan peserta didik untuk belajar mandiri (Haryadi et al., 2015). Peserta didik melakukan pengamatan, mencari informasi, mengungkapkan gagasan, bertanya, menjawab dan saling berdiskusi dalam proses pembelajaran.

Penerapan model pembelajaran berbasis masalah terbukti dapat meningkatkan hasil belajar peserta didik sebagaimana ditunjukkan dari hasil penelitian Siregar et al. (2012), Wijayanti et al. (2013), dan Wiradana (2013). Selain itu, Ikman et al. (2016), Gholami et al. (2016), Sulaiman (2013) juga membuktikan bahwa penggunaan model pembelajaran berbasis 
masalah mampu meningkatkan keterampilan berpikir kritis peserta didik bila dibandingkan penggunaan model pembelajaran konvensional. Oleh karena itu, dalam penelitian ini peneliti telah menguji bagaimana efektivitas model pembelajaran berbasis masalah berbantuan situs jejaring sosial Edmodo terhadap keterampilan berpikir kritis dan hasil belajar kognitif peserta didik.

Arends (2012) mengemukakan tahap-tahap dalam model pembelajaran berbasis masalah. Tahap-tahap pembelajaran dalam model pembelajaran berbasis masalah tersebut bisa dilihat pada Tabel 1 .

Tabel 1. Tahap-tahap pembelajaran dengan model pembelajaran berbasis masalah.

\begin{tabular}{|c|c|c|}
\hline No & Tahapan & Perilaku guru \\
\hline 1 & $\begin{array}{l}\text { Mengorientasikan peserta } \\
\text { didik pada masalah }\end{array}$ & $\begin{array}{l}\text { 1. Guru membahas tujuan pelajaran, mendeskripsikan } \\
\text { berbagai kebutuhan logistik penting, dan memotivasi } \\
\text { peserta didik untuk terlibat dalam kegiatan mengatasi } \\
\text { masalah. }\end{array}$ \\
\hline 2 & $\begin{array}{l}\text { Mengorganisasikan peserta } \\
\text { didik untuk belajar. }\end{array}$ & $\begin{array}{l}\text { 2. Guru membantu peserta didik untuk mendefinisikan dan } \\
\text { mengorganisasikan tugas-tugas belajar yang terkait } \\
\text { dengan permasalahannya. }\end{array}$ \\
\hline 3 & $\begin{array}{l}\text { Membantu investigasi } \\
\text { mandiri dan kelompok. }\end{array}$ & $\begin{array}{l}\text { 3. Guru mendorong peserta didik untuk mendapatkan } \\
\text { informasi yang tepat, melaksanakan eksperimen, } \\
\text { dan mencari penjelasan dan solusi. }\end{array}$ \\
\hline 4 & $\begin{array}{l}\text { Mengembangkan dan } \\
\text { mempresentasikan artefak } \\
\text { dan exhibit. }\end{array}$ & $\begin{array}{l}\text { 4. Guru membantu peserta didik dalam merencanakan dan } \\
\text { menyiapkan artefak-artefak yang tepat, seperti laporan, } \\
\text { rekaman video, dan model-model, dan membantu } \\
\text { mereka untuk menyampaikannya pada orang lain. }\end{array}$ \\
\hline 5 & $\begin{array}{l}\text { Menganalisis dan menge- } \\
\text { valuasi proses mengatasi } \\
\text { masalah. }\end{array}$ & $\begin{array}{l}\text { 5. Guru membantu peserta didik untuk melakukan } \\
\text { refleksi terhadap investigasinya dan proses-proses } \\
\text { yang mereka gunakan. }\end{array}$ \\
\hline
\end{tabular}

Model pembelajaran berbasis masalah bisa dikembangkan dengan mengolaborasikan dengan situs jejaring sosial. Seperti halnya Sinprakob and Songkram (2015) yang telah melakukan penelitian dengan model pembelajaran berbasis masalah menggunakan bantuan situs jejaring sosial Facebook untuk meningkatkan keterampilan berpikir kritis dan kreatif.

Indikator keterampilan berpikir kritis yang diuji merujuk pada indikator keterampilan berpikir kritis yang dikemukakan Raymond et al (2018) yaitu (1) memfokuskan pertanyaan, (2) menganalisis pertanyaan, (3) bertanya dan menjawab pertanyaan tentang suatu penjelasan atau 
tantangan, (4) mencari informasi, dan (5) penalaran logis. Hasil belajar yang diukur adalah hasil belajar kognitif.

Berdasarkan latar belakang yang telah diuraikan di atas, rumusan masalah dalam penelitian ini adalah (1) bagaimana keefektifan model pembelajaran berbasis masalah berbantuan situs jejaring sosial Edmodo dalam meningkatkan keterampilan berpikir kritis peserta didik? (2) bagaimana keefektifan model pembelajaran berbasis masalah berbantuan situs jejaring sosial Edmodo dalam meningkatkan hasil belajar kognitif peserta didik?

Diharapkan, hasil penelitian ini memberikan manfaat antara lain (1) meningkatkan keterampilan berpikir kritis dan hasil belajar kognitif peserta didik terhadap pembelajaran IPA, (2) memperluas wawasan guru mengenai model pembelajaran IPA yang ada, (3) dapat dijadikan sebagai bahan pertimbangan untuk memilih model pembelajaran IPA yang interaktif, (4) memotivasi guru untuk memanfaatkan model pembelajaran berbantuan situs jejaring sosial Edmodo pada materi pembelajaran IPA pokok bahasan yang lain, dan (5) dapat dijadikan acuan dalam pemanfaatan model pembelajaran berbantuan situs jejaring sosial Edmodo pada materi dan mata pelajaran lain.

\section{B. Metode}

Metode penelitian yang digunakan dalam penelitian ini adalah metode eksperimen dengan tipe Pretest-Posttest Control Group Design, seperti ditunjukkan pada Gambar 1.

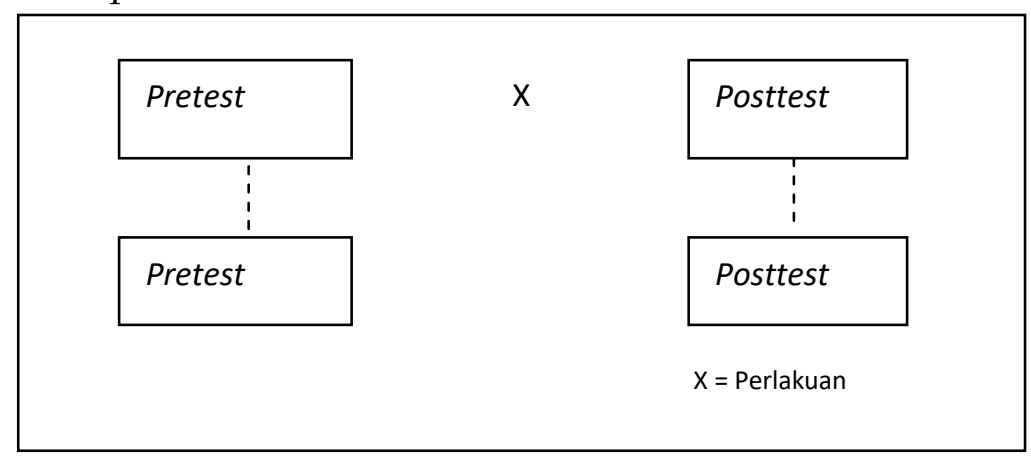

Sumber: Sugiyono (2012)

Gambar 1. Pretest-Posttest Control Group Design 
Populasi penelitian ini adalah peserta didik kelas VIII SMP Negeri 6 Jepara Tahun Pelajaran 2019/2020 berjumlah 224 peserta didik. Sampel dalam penelitian ini adalah peserta didik kelas VIII-F dengan jumlah 32 peserta didik sebagai kelas kontrol, dan kelas VIII-G sebagai kelas eksperimen dengan jumlah 32 peserta didik yang terpilih secara acak. Variabel penelitian ini yaitu variabel bebas meliputi model pembelajaran berbasis masalah berbantuan jejaring sosial Edmodo, variabel terikat meliputi: keterampilan berpikir kritis dan hasil belajar kognitif, sedangkan variabel kontrol meliputi: kurikulum, guru, materi pembelajaran, dan jumlah jam pelajaran yang sama.

Teknik pengumpulan data yang digunakan untuk mengumpulkan data pada penelitian ini disusun berdasarkan variabel-variabel yang diteliti sebagai berikut. (1) Metode tes; tes digunakan untuk mendapatkan data mengenai keterampilan berpikir kritis dan hasil belajar peserta didik. Metode tes ini berupa soal tes berbentuk uraian untuk mengukur keterampilan berpikir kritis dan soal tes pilihan ganda untuk mengukur hasil belajar peserta didik, (2) Observasi; Metode observasi digunakan untuk memberi penguatan terhadap hasil pengambilan data keterampilan berpikir kritis peserta didik. Lembar observasi disusun berdasarkan indikator keterampilan berpikir kritis peserta didik.

Instrumen dalam proses pembelajaran pada penelitian ini meliputi beberapa perangkat antara lain: silabus, RPP, bahan ajar dan situs jejaring sosial Edmodo yang berisi konten video, gambar, forum diskusi, dan quiz.

Peningkatan skor rata-rata pre-test dan post-test dihitung menggunakan rumus gain rata-rata ternormalisasi, yaitu perbandingan gain rata-rata aktual dengan gain rata-rata maksimum (Wiyanto, 2008). Rumus gain yang digunakan sebagai berikut.

$$
N \text { gain }=\frac{S_{\text {post }}-S_{\text {pre }}}{100-S_{\text {pre }}}
$$


Besarnya nilai Ngain menunjukkan keefektifan perlakuan di mana signifikannya ditentukan dengan t-test menggunakan program SPSS dikategorikan pada Tabel 2.

Tabel 2: Kriteria Keefektifan Perlakuan Berdasar Hasil t test

\begin{tabular}{cc}
\hline Ngain & Kriteria \\
\hline Ngain $\leq 0,3$ & Rendah \\
$0,3<$ Ngain $<0,7$ & Sedang \\
Ngain $\geq 0,7$ & Tinggi \\
\hline
\end{tabular}

Analisis uji $\mathrm{t}$ terhadap uji hipotesis keterampilan berpikir kritis dan hasil belajar dengan menggunakan program SPSS. Harga $t$ yang diperoleh selanjutnya dikonsultasikan dengan harga table dengan taraf kesalahan $5 \%$.

\section{Hasil dan Pembahasan}

\section{Hasil}

a. Keefektifan Model Pembelajaran Berbasis Masalah Berbantuan Situs Jejaring Sosial Edmodo terhadap Keterampilan Berpikir Kritis Peserta Didik

Data keterampilan berpikir kritis peserta didik dengan menggunakan model pembelajaran berbasis masalah berbantuan situs jejaring sosial Edmodo diperoleh dari metode tes uraian yang disusun berdasarkan indikator keterampilan berpikir kritis. Berdasarkan penelitian yang telah dilakukan didapatkan hasil rerata skor pretest-posttest kelas kontrol mengalami peningkatan dari 48,94 menjadi 56,78, demikian pula hasil rerata skor pretest-posttest kelas eksperimen juga mengalami peningkatan dari 48,11 menjadi 79,63. Data rerata skor pretest-posttest keefektifan model pembelajaran berbasis masalah berbantuan situs jejaring sosial Edmodo terhadap keterampilan berpikir kritis pada kelas kontrol dan kelas eksperimen disajikan pada Tabel 3.

Tabel 3: Rerata Skor Pretest dan Posstest

\begin{tabular}{cccccc}
\hline \multirow{2}{*}{ No } & \multirow{2}{*}{ Nilai } & \multicolumn{2}{c}{ Kontrol } & \multicolumn{2}{c}{ Eksperimen } \\
\cline { 3 - 6 } & & Pre-test & Post-test & Pre-test & Post-test \\
\hline 1 & Terendah & 40 & 47 & 40 & 77 \\
2 & Tertinggi & 58 & 62 & 66 & 93 \\
3 & Rata-rata & 48,94 & 56,78 & 48,11 & 79,89 \\
\hline
\end{tabular}


Data rerata skor pretest-posttest efektivitas model pembelajaran berbasis masalah berbantuan situs jejaring sosial Edmodo terhadap keterampilan berpikir kritis menggunakan soal tes uraian berdasarkan indikator keterampilan berpikir kritis pada kelas kontrol disajikan pada Tabel 4.

\begin{tabular}{cccc}
\multicolumn{2}{c}{ Tabel 4: Rerata Skor Pretest dan Posstes pada Kelas Kontrol } \\
\cline { 3 - 4 } No & \multirow{2}{*}{ Indikator Berpikir kritis } & \multicolumn{3}{c}{ Rerata } \\
\cline { 3 - 4 } & 1 & 32,45 & Pre-test \\
2 & 2 & 26,77 & 42,78 \\
3 & 3 & 19,64 & 35,04 \\
4 & 4 & 15,22 & 28,55 \\
5 & 5 & 21,49 & 59,01 \\
\hline
\end{tabular}

Keterangan indikator keterampilan berpikir kritis:

$1=$ memfokuskan pertanyaan

2 = menganalisis pertanyaan

3 = bertanya dan menjawab pertanyaan tentang suatu penjelasan atau tantangan

$4=$ mencari informasi

5 = penalaran logis

Data rerata skor pretest-posttest efektivitas model pembelajaran berbasis masalah berbantuan situs jejaring sosial Edmodo terhadap keterampilan berpikir kritis menggunakan soal tes uraian berdasarkan indikator keterampilan berpikir kritis pada kelas eksperimen disajikan pada Tabel 5.

Tabel 5: Rerata Skor Pretest dan Posstes pada Kelas Eksperimen

\begin{tabular}{cccc}
\hline \multirow{2}{*}{ No } & \multirow{2}{*}{ Indikator Berpikir kritis } & \multicolumn{2}{c}{ Rerata } \\
\cline { 3 - 4 } & 1 & Pre-test & Post-test \\
\hline 1 & 2 & 41,25 & 66,92 \\
2 & 3 & 36,09 & 82,23 \\
3 & 4 & 32,78 & 90,82 \\
4 & 5 & 25,24 & 71,05 \\
5 & 41,41 & 86,57 \\
\hline
\end{tabular}

Keterangan indikator keterampilan berpikir kritis:

$1=$ memfokuskan pertanyaan

2 = menganalisis pertanyaan

3 = bertanya dan menjawab pertanyaan tentang suatu penjelasan atau tantangan

$4=$ mencari informasi

5 = penalaran logis 
Data penelitian menunjukkan bahwa pembelajaran IPA dengan model pembelajaran berbasis masalah berbantuan situs jejaring sosial Edmodo dapat meningkatkan setiap indikator keterampilan berpikir kritis peserta didik. Tabel 4. dan Tabel 5. menunjukkan bahwa aspek memfokuskan pertanyaan, menganalisis pertanyaan, bertanya dan menjawab pertanyaan tentang suatu penjelasan atau tantangan, menginduksi dan mempertimbangkan, membuat dan menentukan nilai pertimbangan kelas eksperimen mengalami peningkatan yang signifikan dibandingkan dengan kelas kontrol.

Peningkatan efektivitas model pembelajaran berbasis masalah berbantuan situs jejaring sosial Edmodo terhadap keterampilan berpikir kritis peserta didik pada kelas kontrol dan kelas eksperimen pada setiap indikator berpikir kritis menggunakan rumus Ngain disajikan pada Tabel 6 .

Tabel 6: Peningkatan Efektivitas Model Pembelajaran terhadap Keterampilan Berpikir Kritis

\begin{tabular}{cccc}
\hline \multirow{2}{*}{ No } & \multirow{2}{*}{ Indikator Berpikir kritis } & \multicolumn{2}{c}{ N-gain } \\
\cline { 3 - 4 } & 1 & Kontrol & Eksperimen \\
\hline 1 & 2 & 0,19 & 0,35 \\
2 & 3 & 0,18 & 0,70 \\
3 & 4 & 0,22 & 0,79 \\
4 & 5 & 0,40 & 0,67 \\
5 & 5 & \multicolumn{2}{c}{} \\
\hline
\end{tabular}

Data hasil penilaian efektivitas pembelajaran berbasis masalah berbantuan situs jejaring sosial Edmodo terhadap keterampilan berpikir kritis dikuatkan dengan pengamatan melalui lembar observasi berdasarkan aspek-aspek keterampilan berpikir kritis. Hasilnya disajikan pada Tabel 7. Tabel 7: Penilaian Efektivitas Pembelajaran

\begin{tabular}{cccccc}
\hline \multirow{2}{*}{ No } & \multirow{2}{*}{ Nilai } & \multicolumn{2}{c}{ Kontrol } & \multicolumn{2}{c}{ Eksperimen } \\
\cline { 3 - 6 } & & Pre-test & Post-test & Pre-test & Post-test \\
\hline 1 & Teremdah & 22 & 36 & 36 & 59 \\
2 & Tertinggi & 59 & 82 & 73 & 90 \\
3 & Rata-rata & 39,14 & 59,95 & 41,35 & 75,11 \\
\hline
\end{tabular}

b. Keefektifan Model Pembelajaran Berbasis Masalah Berbantuan Situs Jejaring Sosial Edmodo terhadap Hasil Belajar Peserta Didik. 
Data keefektifan model pembelajaran berbasis masalah berbantuan situs jejaring sosial Edmodo terhadap hasil belajar diperoleh dari tes hasil belajar. Soal-soal tes hasil belajar sebelumnya telah dilakukan uji validasi butir soal, uji tingkat kesukaran, uji daya beda, dan uji reliabilitas dengan cara diujikan pada kelompok lain di luar kelompok sampel. Seperti halnya lembar observasi keterampilan berpikir kritis, tes hasil belajar juga diberikan kepada kelompok kontrol dan kelompok eksperimen di awal dan di akhir pertemuan materi pembelajaran. Peningkatan hasil belajar peserta didik pada kelas kontrol dan kelas eksperimen dapat dilihat pada Tabel 8.

Tabel 8: Peningkatan Hasil Belajar Peserta Didik

\begin{tabular}{ccccc}
\hline \multirow{2}{*}{ No } & \multicolumn{2}{c}{ Kontrol } & \multicolumn{2}{c}{ Eksperimen } \\
\cline { 2 - 5 } & Pre-test & Post-test & Pre-test & Post-test \\
\hline 1 & 25 & 47 & 34 & 52 \\
2 & 69 & 86 & 71 & 92 \\
3 & 45,67 & 67,16 & 49,02 & 78,91 \\
\hline
\end{tabular}

\section{Pembahasan}

Data hasil penelitian menunjukkan bahwa pembelajaran IPA dengan model pembelajaran berbasis masalah berbantuan situs jejaring sosial Edmodo dapat meningkatkan indikator keterampilan berpikir kritis peserta didik. Tabel 6. menunjukkan bahwa aspek memfokuskan pertanyaan, menganalisis pertanyaan, bertanya dan menjawab pertanyaan tentang suatu penjelasan atau tantangan, menginduksi dan mempertimbangkan, membuat dan menentukan nilai pertimbangan kelas eksperimen mengalami peningkatan yang lebih tinggi dibandingkan dengan kelas kontrol. Hal ini sesuai dengan penelitian yang telah dilakukan oleh Suparya (2020) yang menggunakan model pembelajaran berbasis masalah berbantuan situs jejaring sosial Edmodo mampu meningkatkan keterampilan berpikir kritis peserta didik.

Peningkatan keterampilan memfokuskan pertanyaan peserta didik kelas eksperimen sebesar 0,35 dengan kategori sedang. Peningkatan keterampilan memfokuskan pertanyaan kelas kontrol adalah 0,19 dengan kategori rendah. Hasil uji t keterampilan memfokuskan pertanyaan peserta didik diperoleh 
$t_{\text {hitung }}$ 2,16 $>t_{\text {tabel }} 1,99$ yang berarti bahwa peningkatan keterampilan memfokuskan pertanyaan peserta didik kelas eksperimen lebih baik dibandingkan dengan keterampilan memfokuskan pertanyaan kelas kontrol.

Keterampilan menganalisis pertanyaan peserta didik kelas eksperimen mengalami peningkatan sebesar 0,70 dengan kategori tinggi. Peningkatan keterampilan menganalisis pertanyaan kelas kontrol adalah 0,18 dengan kategori rendah. Hasil uji $\mathrm{t}$ keterampilan menganalisis pertanyaan peserta didik diperoleh $t_{\text {hitung }}$ 5,17 $>t_{\text {tabel }}$ 1,99 yang berarti bahwa peningkatan keterampilan menganalisis pertanyaan peserta didik kelas eksperimen lebih baik dibandingkan dengan keterampilan menganalisis pertanyaan kelas kontrol.

Peningkatan keterampilan bertanya dan menjawab pertanyaan tentang suatu penjelasan atau tantangan peserta didik kelas eksperimen sebesar 0,79 dengan kategori tinggi. Peningkatan keterampilan bertanya dan menjawab pertanyaan tentang suatu penjelasan atau tantangan peserta didik kelas kontrol adalah 0,25 dengan kategori rendah. Hasil uji $t$ keterampilan bertanya dan menjawab pertanyaan tentang suatu penjelasan atau tantangan peserta didik diperoleh $t_{\text {hitung }} 10,37>t_{\text {tabel }} 1,99$ yang berarti bahwa peningkatan keterampilan bertanya dan menjawab pertanyaan tentang suatu penjelasan peserta didik kelas eksperimen lebih baik dibandingkan dengan keterampilan bertanya dan menjawab pertanyaan tentang suatu penjelasan kelas kontrol.

Keterampilan menginduksi dan mempertimbangkan hasil induksi peserta didik kelas eksperimen mengalami peningkatan sebesar 0,67 dengan kategori sedang. Peningkatan keterampilan menginduksi dan mempertimbangkan hasil induksi kelas kontrol adalah 0,22 dengan kategori rendah. Hasil uji t keterampilan menginduksi dan mempertimbangkan hasil induksi peserta didik diperoleh $t_{\text {hitung }} 11,12>t_{\text {tabel }}$ 1,99 yang berarti bahwa peningkatan keterampilan menginduksi dan mempertimbangkan hasil induksi peserta didik kelas eksperimen lebih baik dibandingkan 
dengan keterampilan menginduksi dan mempertimbangkan hasil induksi peserta didik kelas kontrol.

Peningkatan keterampilan membuat dan menentukan nilai pertimbangan peserta didik kelas eksperimen sebesar 0,75 dengan kategori tinggi, demikian pula peningkatan keterampilan membuat dan menentukan nilai pertimbangan kelas kontrol 0,40 dengan kategori sedang. Hasil uji $\mathrm{t}$ keterampilan membuat dan menentukan nilai pertimbangan peserta didik diperoleh $t_{\text {hitung }} 4,92>t_{\text {tabel }} 1$,99. Ini berarti bahwa peningkatan keterampilan membuat dan menentukan nilai pertimbangan peserta didik kelas eksperimen lebih baik dibandingkan dengan keterampilan membuat dan menentukan nilai pertimbangan peserta didik kelas kontrol.

Peningkatan keterampilan berpikir kritis kelas eksperimen secara keseluruhan lebih baik dibandingkan keterampilan berpikir kritis kelas kontrol karena pembelajaran berbasis masalah berbantuan situs jejaring sosial Edmodo mampu melatih peserta didik untuk terbiasa memberi penjelasan sederhana terhadap suatu permasalahan secara fleksibel tanpa harus takut mengutarakan ide yang dimiliki melalui lisannya.

Pembelajaran berbasis masalah berbantuan situs jejaring sosial Edmodo dapat meningkatkan kemampuan berpikir kritis peserta didik melalui langkah-langkahnya yaitu menganalisis dan mengevaluasi proses mengatasi masalah. Peserta didik mampu mengidentifikasi masalah yang dikemukakan saat membahas materi tekanan pada zat cair dan memberikan penjelasan sederhana tentang konsep tersebut. Keterampilan berpikir kritis tampak pada percakapan dalam forum diskusi antara peneliti dan peserta didik melalui situs jejaring sosial Edmodo.

Pembelajaran berbasis masalah dalam penelitian ini efektif untuk meningkatkan keterampilan berpikir kritis dan hasil belajar peserta didik, dapat terlihat dari peningkatan rerata skor pretest dan postest keterampilan berpikir kritis kelas kontrol dan kelas eksperimen. Hal ini sesuai dengan penelitian yang dilakukan oleh Rahmawati (2021), Ariani (2020), Utama et al. (2020), Dewi (2020), Misla et al. (2020), Fatmawati et al. (2018), Herzon et 
al. (2018), Farisi et al. (2017), dan Herayanti et al. (2015) yang memperoleh hasil bahwa keterampilan berpikir peserta didik yang diajarkan dengan pembelajaran berbasis masalah lebih baik dari pada keterampilan berpikir kritis yang diajarkan dengan pembelajaran konvensional.

Pembelajaran dengan menggunakan situs jejaring sosial Edmodo dalam penelitian ini juga sangat efektif untuk meningkatkan keterampilan berpikir kritis peserta didik, dapat terlihat dari peningkatan rerata skor pretest dan postest keterampilan berpikir kritis kelas kontrol dan kelas eksperimen. Hal ini sesuai dengan penelitian yang dilakukan oleh Hal ini senada dengan penelitian yang telah dilakukan oleh Zainudin et al. (2019), Ratnawati (2020), dan Bilkisda et al. (2021) yang menggunakan situs jejaring sosial Edmodo mampu meningkatkan keterampilan berpikir kritis peserta didik.

Data efektivitas pembelajaran berbasis masalah berbantuan situs jejaring sosial Edmodo terhadap keterampilan berpikir kritis dikuatkan dengan pengamatan melalui lembar observasi berdasarkan indikator keterampilan berpikir kritis. Berdasarkan penelitian yang telah dilakukan telah didapatkan hasil rerata skor pengamatan keterampilan berpikir kritis kelas kontrol mengalami peningkatan dari 39,14 menjadi 59,95, demikian pula hasil rerata skor penilaian keterampilan berpikir kritis kelas eksperimen juga mengalami peningkatan dari 41,35 menjadi 75,11. Data peningkatan keterampilan berpikir kritis melalui lembar observasi disajikan pada Tabel 5 .

Tabel 8. terlihat bahwa hasil belajar peserta didik meningkat, yaitu pada kelas kontrol dari rata-rata nilai 45,67 menjadi 67,16 dan pada kelas eksperimen meningkat dari 49,02 untuk pretest menjadi 78,91 untuk posttest. Nilai rata-rata kelas kontrol mengalami peningkatan sebesar 21,49. Nilai rata-rata kelas eksperimen juga mengalami peningkatan sebesar 29,89. Secara terinci nilai terendah dan tertinggi peserta didik juga mengalami peningkatan. Nilai terendah pretest peserta didik pada kelas kontrol sebesar 25 meningkat menjadi 47 dan nilai terendah pada kelas eksperimen meningkat dari 34 menjadi 52. Nilai tertinggi pretest peserta didik pada 
kelas kontrol meningkat dari 69 menjadi 86 dan pada kelas eksperimen meningkat dari 71 meningkat menjadi 92.

Hasil penelitian menunjukkan bahwa peningkatan hasil belajar kelas eksperimen sebesar 0,49 dalam kategori sedang, nilai ini lebih tinggi dibandingkan dengan peningkatan hasil belajar kelas kontrol sebesar 0,34. Hasil uji $t$ mengenai hasil belajar peserta didik diperoleh $t_{\text {hitung }} 2,757>t_{\text {tabel }}$ 1,99. Hal ini menunjukkan bahwa hasil belajar kelas eksperimen mengalami peningkatan yang signifikan dibandingkan dengan kelas kontrol. Peningkatan hasil belajar kelas eksperimen ini senada dengan penelitian Nee (2014) yang mendapatkan hasil bahwa peserta didik yang menggunakan pembelajaran dengan situs jejaring sosial Edmodo memiliki nilai gain yang tinggi dibandingkan peserta didik yang mendapatkan pembelajaran dengan metode ceramah. Peningkatan hasil belajar peserta didik dengan menggunakan situs jejaring sosial Edmodo juga didukung oleh penelitian Lanusi (2018) yang menyatakan pembelajaran kelas digital Edmodo dapat meningkatkan minat dan hasil belajar peserta didik kelas VI A SDN NO. 86 Kota Gorontalo. Hasil penelitian ini senada dengan yang dilakukan oleh Fatmawarni (2018), Furi et al. (2018), Maliawan et al. (2015), dan Surya et al. (2018). Peningkatan hasil belajar peserta didik juga didukung oleh penelitian Daulay et al. (2016) bahwa terdapat peningkatan hasil belajar peserta didik yang menggunakan blended learning berbasis situs jejaring sosial Edmodo pada pembelajaran IPA biologi dibandingkan dengan hasil belajar peserta didik yang menggunakan metode konvensional. Penelitian serupa juga dilakukan oleh Alshawi et al. (2016), Amin (2017), Anggraini et al. (2016), Ekawati (2018), Fauzi (2017), Mardliyana et al. (2018), Putra (2015), Rahmawati (2015), dan Tripathi (2016).

Menurut Puji \& Umamah (2018), kelebihan situs jejaring sosial Edmodo adalah sebagai berikut. (1) Guru dan peserta didik dapat berdiskusi secara aman dan tertutup; (2) Guru dapat mengontrol interaksi antar peserta didik; (3) Guru dapat memfasilitasi forum diskusi antar peserta didik; (4) Guru dapat memosting tugas dan melakukan evaluasi secara 
cepat; (5) Guru dapat mengetahui pemahaman peserta didik tentang materi yang disajikan; (6) Guru dan peserta didik dapat menyimpan dan berbagi dokumen dan file; (7) Guru dapat memiliki perpustakaan pribadi dan berbagi konten dengan peserta didik; (8) Orang tua dapat membuat akun terpisah yang berfungsi untuk mengontrol pembelajaran; dan (9) Situs jejaring sosial Edmodo dapat digunakan di luar jam pelajaran. Sedangkan kekurangan situs jejaring sosial Edmodo (Basori, 2013) adalah (1) situs jejaring sosial Edmodo belum menyediakan sintaks online secara langsung dan (2) Jaringan internet yang kurang stabil menjadikan kendala penggunaan situs jejaring sosial Edmodo.

\section{Penutup}

Model pembelajaran berbasis masalah berbantuan situs jejaring sosial Edmodo efektif untuk meningkatkan keterampilan berpikir kritis peserta didik pada keseluruhan aspek keterampilan berpikir kritis, dimana aspek memfokuskan pertanyaan, menganalisis pertanyaan, bertanya dan menjawab pertanyaan tentang suatu penjelasan atau tantangan, menginduksi dan mempertimbangkan, membuat dan menentukan nilai pertimbangan kelas eksperimen mengalami peningkatan yang lebih tinggi dibandingkan dengan kelas kontrol dengan $N_{\text {gain }}$ masing-masing: 0,35; 0,$70 ; 0,79 ; 0,67 ; 0,75$ dan memiliki perbedaan yang signifikan.

Model pembelajaran berbasis masalah berbantuan situs jejaring sosial Edmodo efektif untuk meningkatkan hasil belajar peserta didik dengan $N_{\text {gain }}$ 0,49 dengan kategori sedang dan memiliki perbedaan yang signifikan antara peserta didik yang diajar dengan menggunakan model pembelajaran berbasis masalah dengan peserta didik yang diajar dengan pembelajaran berbasis masalah berbantuan situs jejaring sosial Edmodo.

Penggunaan model pembelajaran berbasis masalah berbantuan situs jejaring sosial Edmodo terbukti efektif dalam meningkatkan kemampuan keterampilan berpikir kritis dan hasil belajar peserta didik kelas VIII $\mathrm{F}$ SMP Negeri 6 Jepara pada pokok bahasan tekanan dan penerapannya 
dalam kehidupan sehari-hari. Situs jejaring sosial Edmodo memberikan forum diskusi tanpa batas ruang dan waktu dalam pembelajaran sehingga bisa dimanfaatkan peserta didik untuk mengutarakan pendapat dan meningkatkan hasil belajarnya. Situs jejaring sosial Edmodo juga bisa dimanfaatkan oleh guru untuk materi dan pelajaran lain.

\section{Ucapan Terima Kasih}

Peneliti menyadari bahwa tanpa bantuan dari berbagai pihak maka laporan Penelitian Tindakan Kelas ini tidak akan pernah terwujud. Pada kesempatan ini peneliti mengucapkan terima kasih kepada Darono Ardi Widodo, S.Pd.Ind, selaku Kepala SMP Negeri 6 Jepara, Bapak Ibu dewan guru SMP Negeri 6 Jepara, dan semua pihak yang tidak dapat disebutkan satu persatu yang telah membantu penyelesaian penelitian ini.

\section{Daftar Referensi}

Alshawi, S., Turki., \& Alhomoud, F. A. (2016). The Impact of Using Edmodo on Saudi University EFL Students' Motivation and Teacher-Student Communication. International Journal of Education, 8 (4), 105-121.

Amin, A. K. (2017). Kajian Konseptual Model Pembelajaran Blended Learning berbasis Web untuk Meningkatkan Hasil Belajar dan Motivasi Belajar. Jurnal Pendidikan Edutama, 4 (2), 51-64.

Anggraini, A. D., Wonorahardjo, S., \& Utomo, Y. (2016). Efektivitas Pembelajaran Blended Learning Berbasis Community of Inquiry (CoI) Ditinjau dari Hasil Belajar Kognitif Mahasiswa pada Materi Kromatografi. Prosiding Seminar Nasional II Tahun 2016. Prodi Pendidikan Biologi FKIP Universitas Muhammadiyah Malang.

Basori. (2013). Pemanfaatan Social Learning Network "Edmodo" dalam Membantu Perkuliahan Teori Bodi Otomotif di Prodi PTM. Jurnal Ilmu Pengetahuan \& Teknologi, 4 (2), 99-105.

Bilkisda, I. Z., \& Sudibyo, E. (2021). Pengaruh Pembelajaran e-Learning Edmodo terhadap Kemampuan Berpikir Kritis Siswa SMP pada Materi Kalor dan Perpindahannya. PENSA e-Jurnal Pendidikan Sains. 9 (2). 193-198. 
Daulay, U. A., Syarifuddin, \& Manurung, B. (2016). Pengaruh Blended Learning Berbasis Edmodo dan Motivasi Belajar Terhadap Hasil Belajar IPA Biologi dan Retensi Siswa pada Sistem Peredaran Darah Manusia di Kelas VIII SMP Negeri 5 Medan. Jurnal Pendidikan Biologi, 6 (1). 262-266

Dewi, D. T. (2020). Penerapan Problem Based Learning untuk Meningkatkan Kemampuan Berpikir Kritis Siswa. Jurnal Pendidikan Ekonomi Undiksha. 12 (1).

Ekawati, N. E. (2018). Penerapan Blended Learning dengan Aplikasi Edmodo Berbasis Strategi Pembelajaran PDEODE untuk Meningkatkan Prestasi Belajar Siswa. Jurnal Ilmiah Pendidikan MIPA, 8 (1), 7-16.

Eid, M. I. M. \& Al-Jabri, I. M. (2016). Social Networking, Knowledge Sharing, and Student Learning : The Case of University Students. Elsevier. Computers in Human Behavior, 99, 14-27.

Enriquez, M. A. S. (2014). Students' Perceptions on the Effectiveness of the Use of Edmodo as a Supplementary Tool for Learning. DLSU Research Congress 2014, De La Salle University, Manila, Philippines, 1-6.

Farisi, A. et. al. (2017). Pengaruh Model Pembelajaran Problem Based Learning terhadap Kemampuan Berpikir Kritis dalam Meningkatkan Hasil Belajar Siswa pada Konsep Suhu dan Kalor. Juirnal Ilmiah Mahasiswa Pendidikan Fisika. 2 (3). 283-287.

Fatmawarni, Haryani, P., \& Putri. (2018). Penerapan Model Pembelajaran Project Based Learning (PjBL) dalam Meningkatkan Hasil Belajar Analisa Ratio Keuangan pada Program Studi Pendidikan Akuntansi FKIP UMSU. Jurnal Pendidikan Akuntansi, 1 (1), 24-47.

Fatmawati, E. T., \& Sujatmika, S. (2018). Efektivitas Pembelajaran Problem Based Learning terhadap Hasil Belajar IPA Ditinjau dari Kemampuan Berpikir Kritis. Wacana Akademika. 2 (2). 163-171.

Fauzi, A. (2017). The Effect of Edmodo on Students' Writing Skill in Recount Text. International Journal of Pedagogy and Teacher Education (IJPTE), 1 (2), 73-79.

Furi, L. M. I., Handayani, S., \& Maharani, S. (2018). Eksperimen Model Pembelajaran Project Based Learning Dan Project Based LearningTerintegrasi Stem Untuk Meningkatkan Hasil Belajar Dan Kreativitas Siswa Pada Kompetensi Dasar Teknologi Pengolahan Susu. Jurnal Penelitian Pendidikan, 35 (1), 49-60. 
Gholami, M., Moghadam, P. K., Mohammadipoor, F., Tarahi, M. J., Sak, M., Toulabi, T., \& Pour, A. H. H. (2016). Comparing The Effects of Problem-Based Learning and The Traditional Lecture Method on Critical Thinking Skills and Metacognitive Awareness in Nursing Students in A Critical Care Nursing Course. Nurse Education Today Journal, 45, 16-21.

Haryadi, E. F., Priyono, A., \& Retnoningsih, A. (2015). Desain Pembelajaran Literasi Sains Berbasis Problem Based Learning Dalam Membentuk Keterampilan Berpikir Kritis Siswa. Journal of Innovative Science Education, 4 (2), 1-7.

Herayanti, L., \& Habibi. (2015). Model Pembelajaran Berbasis Masalah Berbantuan Simulasi Komputer untuk Meningkatkan Keterampilan Berpikir Kritis Calon Guru Fisika. Jurnal Pendidikan Fisika dan Teknologi. 1 (1). 61-66.

Herzon, H. H., et. al. (2018). Pengaruh Problem-Based Learning (PBL) terhadap Keterampilan Berpikir Kritis. Jurnal Pendidikan. 3 (1). $42-46$.

Ikman, Hasnawati, \& Rezky, M. F. (2016). Effect of Problem Based Learning (PBL) Models of Critical Thinking Ability Students on The Early Mathematics Ability. International Journal of Education and Researc, 4(7), 361-374.

Junco, R. (2013). Comparing Actual and Self-Reported Measures of Facebook Use. Elsevier. Computers in Human Behavior, 29, 626-631.

Lanusi, D. H. (2018). Penerapan Kelas Digital Edmodo untuk Meningkatkan Minat Belajar dan Hasil Belajar Siswa. Jurnal Didaktika Pendidikan Dasar. 2 (1). 67-82.

Maliawan, N., Arsa, I. P. S., \& Ariawan, K. U. (2015). Penerapan Model Pembelajaran Project Based Learning (PjBL) untuk Meningkatkan Hasil Belajar Prakarya dan Kewirausahaan (Fisika Terapan) pada Siswa Kelas X IPA 2 SMA Negeri 1 Sukasada Tahun Pelajaran 2014/2015. e-Journal Jurnal JPTE Universitas Pendidikan Ganesha Jurusan Pendidikan Teknik Elektro, 4 (1), 1-11.

Mardliyana, E., Muryani, C., \& Sarwono. (2018). Efektivitas Model Pembelajaran Contextual Teaching and Learning (CTL) dan Berbasis E-Learning Edmodo terhadap Hasil Belajar Siswa pada Materi Langkah Penelitian Geografi di Kelas X IPS SMA dan MA Assalaam Sukoharjo. Jurnal GeoEco, 4 (1), 19-30. 
Misla \& Mawardi. (2020). Efektivitas PBL dan Problem Solving Siswa SD Ditinjau dari Kemampuan Berpikir Kritis. Jurnal Ilmiah Sekolah Dasar. 4 (1). 60-65.

Nee, C. K. (2014). The Effect Of Educational Networking On Students' Performance Inbiology. International Journal on Integrating Technology in Education (IJITE), 3(1), 21-41. doi: 10.5121/ijite.2014.3102

Puji, N. P. R., \& Umamah, N. (2018) Edmodo Multimedia: Supporting Technology for Media Learning at Higher Education. International Journal of English Literature and Social Sciences (IJELS), 3 (1), 48-56.

Putra, A. P. (2015). Pengaruh Penerapan Model Blended Learning Terhadap Prestasi Belajar Sejarah Siswa. Jurnal Candrasangkala, 1 (1), 1-14.

Rachmawati, N. Y., \& Rosy, B. (2021). Pengaruh Model Pembelajaran Problem Based Learning (PBL) terhadap Kemampuan Berpikir Kritis dan Pemecahan Masalah pada Mata Pelajaran Administrasi Umum Kelas X OTKP di SMK Negeri 10 Surabaya. Jurnal Pendidikan Administrasi Perkantoran. 9 (2). 246-259.

Rahmawati, E., Jaenudin, R., \& Fitriyanti. (2015). Pengaruh Media Edmodo terhadap Hasil Belajar Peserta Didik pada Mata Pelajaran Ekonomi di SMA Negeri 1 Indralaya Utara. Jurnal Profit, 2 (2), 1-7.

Ratnawati, F. A. (2020). Efektivitas Model Pembelajaran Problem Possing Berbantuan Edmodo terhadap Pemahaman Konsep Ditinjau dari Keterampilan Proses Sains dan Keterampilan Berpikir Kritis Siswa. Jurnal Dedikasi Pendidikan. 4 (2). 305-322.

Raymond, C., Joanne Profetto-McGrath, J., P., Myrick, F., \& Strean, W., B. (2018). Nurse Educators' Critical Thinking: A Mixed Methods Exploration. Accepted Manuscript. Canada

Sinprakob, S., \& Songkram, N. (2015). A Proposed Model of Problem-Based Learning on Social Media in Cooperation with Searching Technique to Enhance Critical Thinking of Undergraduate Students. Procedia Social and Behavioral Sciences, 174, 2027-2030. doi: 10.1016/j.sbspro.2015.01.871

Siregar, N., Armanto, D., \& Saragih, S. (2012). Penerapan Pembelajaran Berbasis Masalah Untuk Meningkatkan Pemahaman Konsep Dan Pengetahuan Prosedural Matematika Siswa SMP. Jurnal Pendidikan Matematika PARADIKMA, 5(2), 137-150. 
Sudarman. (2018). Pengaruh Strategi Pembelajaran Blended Learning Terhadap Perolehan Belajar Konsep dan Prosedur Pada Mahasiswa Yang Memiliki Self-Regulated Learning Berbeda. Jurnal Pendidikan dan Pembelajaran, 21(1).

Sugiyono. (2012). Metode Penelitian Pendidikan Pendekatan Kuantitatif, Kualitatif dan $R \mathcal{E} D$. Bandung: Alfabeta.

Sulaiman, F. (2013). The Effectiveness of PBL Online on Physics Students' Creativity and Critical Thinking: A Case Study at Universiti Malaysia Sabah International Journal of Education and Research, 1(3), 1-18.

Suparya, I. K. (2020). Peningkatan Motivasi dan Kemampuan Berpikir Kritis Mahasiswa Melalui Model Pembelajaran Berbasis Masalah Berbantuan Media Edmodo. Jurnal Ilmiah Pendidikan Citra Bakti. 7 (1). 1-12.

Surya, A. P., Relmasira, S. C., \& Hardini, A. T. A. (2018). Penerapan Model Pembelajaran Project Based Learning (PjBL) untuk Meningkatkan Hasil Belajar dan Kreatifitas Siswa Kelas III SD Negeri Sidorejo Lor 01 Salatiga. Jurnal Pesona Dasar, 6 (1), 41-54.

Tany, Y. S., \& Utami, T. H. (2013). Penerapan Problem Based Learning (Pbl) Untuk Meningkatkan Hasil Belajar Siswa Di Kelas VII-A SMP Katolik Frateran Celaket 21 Malang. Artikel Ilmiah Universitas Negeri Malang.

Tripathi, H. (2016). Effectiveness of Blended Learning Using LMS-Edmodo in Teaching Economics at Higher Secondary Level . The International Journal of Indian Psychology, 3 (10), 1-10.

Utama, K. H., \& Kristin, F. (2020). Meta-Analisis Pengaruh Model Pembelajaran Problem Based Learning (PBL) terhadap Kemampuan Berpikir Kritis IPA di Sekolah Dasar. Jurnal Basicedu. 4 (4), 889-898.

Wijayanti, M. S. R., Binadja, A., \& Haryani, S. (2013). Pengembangan Model Pembelajaran Larutan Penyangga Berbasis Masalah Bervisi Sets. Journal of Innovative Science Education, 2(1), 57-62

Wiradana, I. W. G. (2013). Penerapan Pembelajaran Berbasis Masalah (Problem- Based Learning) Untuk Mengubah Miskonsepsi Siswa pada Pembelajaran Suhu dan Massa Jenis. Jurnal Ilmiah Disdikpora Kabupaten Klungkung, 2 (1), 1-10.

Zainudin \& Pambudi, B. (2019). Efektifitas Penerapan Perangkat Pembelajaran Fisika Dasar Berbasis Keterampilan Berpikir Kritis Menggunakan Aplikasi Edmodo Berplatform Android. Jurnal Pengkajian Ilmu dan Pembelajaran Matematika dan IPA IKIP Mataram 7 (1), 17-26. 